\title{
Uptake and utilization of 'colloidal DOM' by heterotrophic flagellates in seawater
}

\author{
Lars J. Tranvik ${ }^{1}$, E. B. Sherr ${ }^{2}$, B. F. Sherr ${ }^{2}$ \\ ${ }^{1}$ Dept of Ecology, Limnology, University of Lund, Box 65, S-221 00 Lund, Sweden \\ ${ }^{2}$ College of Oceanography, Oregon State University, Oceanography Admin Bldg 104, Corvallis, Oregon 97331-5503, USA
}

\begin{abstract}
A variety of macromolecules labeled with FITC (fluorescein isothiocyanate), including carbohydrates (dextran) and proteins (ferritin, casein, albumin, concavalin A), spanning a range of molecular weights from 55 to $2000 \mathrm{kD}$, were actively ingested by marine heterotrophic flagellates at substrate concentrations of 1 to $10 \mathrm{mg}^{-1}$. The uptake capacity for the macromolecules was positively correlated to clearance rate for bacterial-sized prey. Ingested FITC appeared in the food vacuoles of the cells. The biomass of a cultured bacterivorous flagellate species increased in cultures amended with $10 \mathrm{mg}$ of $2000 \mathrm{kD}$ dextran $\mathrm{l}^{-1}$ to an extent that could not be explained by bacterivory. However, $40 \mathrm{kD}$ dextran did not stimulate flagellate growth. On the basis of these results, we suggest that protists have the capacity to ingest colloids of widely different sizes, spanning the size range of bacteria and larger organisms to macromolecules, possibly including the recently discovered abundant non-living submicrometer colloids in sea water.
\end{abstract}

\section{INTRODUCTION}

Bacteria are generally considered to be the only pelagic microorganisms that utilize dissolved organic matter (DOM), and thus transform it to a particulate form that can be further processed within aquatic food webs. Feeding on DOM by protists is generally believed not to occur except at concentrations several orders of magnitude above those prevailing in natural waters, as protists are competitively inferior to bacteria in the uptake of low molecular weight dissolved compounds at low concentrations (Haas \& Webb 1979, Fenchel 1987).

DOM is usually defined as the organic matter able to pass a filter of $0.2 \mu \mathrm{m}$ pore size. In addition to truly dissolved compounds DOM comprises a multitude of colloids such as some bacteria that may pass a $0.2 \mu \mathrm{m}$ filter (Stockner et al. 1990), viral particles (Sieburth 1979, Bergh et al. 1989), and less well defined nonliving colloids (Koike et al. 1990, Wells \& Goldberg 1991). It has recently been demonstrated (Koike et al. 1990 ) that at least $10 \%$ of oceanic 'DOM' is in the form of amorphous detrital particles in the size range 0.4 to $1.0 \mu \mathrm{m}$ that easily pass the pores of the $0.2 \mu \mathrm{m}$ filters usually employed in the separation of DOM and particulate organic matter (POM). Due to the ubiquity of these particles, more than $95 \%$ of the bacterial-sized particles in oceanic water were shown to be non-living. Colloids of viral and macromolecular size are also abundant (Bergh et al. 1989, Wells \& Goldberg 1991). The spectrum of non-living colloids exceeds bacteria by one or several orders of magnitude both in particle abundance and total carbon (Koike et al. 1990, Wells \& Goldberg 1991j, and, due to their small average size compared to bacterial cells, also in surface area.

Although phagotrophic protists have not been found to utilize dissolved low molecular weight compounds, they may have the potential to ingest components of the colloidal fraction of DOM. Very little is known about detrital colloidal and non-living particulate organic carbon as a food resource for pelagic, heterotrophic flagellates. Investigators have previously noted the presence of detrital matter in protist food vacuoles (Gast 1985, Sherr \& Sherr 1992). Sherr (1988) detected uptake of fluorescently labeled macromolecules ( 500 to $2000 \mathrm{kD}$ dextran) by flagellates and also flagellate growth at the expense of such compounds. Moreover, González \& Suttle 1993) have demonstrated that flagellates and ciliates are able to ingest and digest viral size particles $(50 \mathrm{~nm}$ fluorescent microspheres and fluorescently labeled marine viruses). 
Here, we present some experiments confirming the previous study of Sherr (1988) which showed that phagotrophic, nanoplanktonic flagellates are able to ingest a high molecular weight carbohydrate. Moreover, we examine this phenomenon in closer detail using a mono-specific culture of a phagotrophic flagellate and mixed assemblages of protists, and expand the evidence for uptake into food vacuoles to several other macromolecules, including high molecular weight proteins.

\section{MATERIALS AND METHODS}

Organisms. A heterotrophic, bacterivorous flagellate (E4, ca 3 to $5 \mu \mathrm{m}$ diameter with 2 equilength flagella, isolated from Oregon, USA, coastal waters) was used in culture experiments to determine ingestion of macromolecules labcled with FITC (fluorescein isothiocyanate) and growth at the expense of high molecular weight materials. This species was able to ingest several different FITC-labelled macromolecules (see below) as well as monodisperse $50 \mathrm{~nm}$ fluorescent microspheres (González \& Suttle 1993). For experiments with mixed assemblages of protists, water was collected from an incoming tide at the Oregon Marine Biology Institute, Charleston, Oregon. Experiments were carried out either directly upon sampling or after incubation to stimulate the growth of protists (prescreened through $20 \mu \mathrm{m}$ mesh netting to exclude predators and incubated in the dark at $15^{\circ} \mathrm{C}$ ). In one case, yeast extract was added to the water $\left(10 \mathrm{mg} \mathrm{l}^{-1}\right)$ to stimulate growth of bacteria and bacterivorous flagellates.

Microscopy. All microscopy was conducted with a Zeiss Universal equipped for epifluorescence $(75 \mathrm{~W}$ Xenon lamp and filter sets for UV and blue excitation, $100 \times$ Neofluar lens). For detection of FITC-labeled macromolecules in flagellate food vacuoles, samples were killed by sequential addition of $20 \mu \mathrm{l}$ alkaline Lugol solution, $0.4 \mathrm{ml}$ borate-buffered formaldehyde, and $20 \mu \mathrm{l} 3 \%$ sodium thiosulfate (Sherr et al. 1993), stained with DAPI (4',6-diamidino-2-phenylindole, $10 \mu \mathrm{g} \mathrm{ml}^{-1}$, final concentration) for 7 to $10 \mathrm{~min}$, and filtered onto $0.8 \mu \mathrm{m}$ black polycarbonate filters (Poretics). Flagellates were identified by their blue DAPI fluorescence upon excitation with UV light. Each flagellate encountered was also inspected with blue light excitation, to determine the presence or absence of yellow-green FITC fluorescence. At least 100 flagellates (50 in the growth/uptake experiment) were inspected in each sample. In the field samples, heterotrophic and autotrophic/mixotrophic forms were distinguished by the absence or presence of chlorophyll autofluorescence (blue excitation). As no FITC uptake was detected in flagellates with chlorophyll fluorescence, FITC uptake results are presented as percentage of heterotrophic flagellates with ingested fluorochrome.

Flagellates and bacteria in field samples were enumerated after DAPI staining. In growth experiments with the flagellate E4, flagellates and bacteria were enumerated and sized after staining with acridine orange (Hobbie et al. 1977). At least 50 flagellates or 250 bacteria and 10 fields of view were counted. In experiments where cell volumes were determined, at least 20 flagellates or 50 bacteria were sized. Diameter of flagellates was estimated by eye-piece micrometer, and the volume of each cell was calculated assuming a spherical shape. Length and width of bacteria were measured from photomicrographs according to Tranvik (1988), and volume of each measured cell was calculated assuming a cylindrical shape with a hemispere at either end.

Uptake experiments. Macromolecules conjugated with FITC used in the experiments included dextran (a bacterially-produced polysaccharide, $2000 \mathrm{kD}$ ), bovine milk casein (protein, $375 \mathrm{kD}$ ), bovine albumin (protein, $67 \mathrm{kD}$ ), succinyl-concavalin A (con A; lectin, $55 \mathrm{kD}$ ), horse spleen ferritin (protein, $650 \mathrm{kD}$ ), and lipopolysaccharide (LPS; bacterial cell wall component). The compounds were purchased from Sigma (St. Louis, MO, USA), except for the ferritin, which was obtained from Molecular Probes (Eugene, OR, USA). Aliquots of the FITC-labeled compounds were dissolved or diluted in $<0.2 \mu \mathrm{m}$ filtered, reagent grade water (E-pure, Barnstead, Dubuque, IA, USA), and filtered $(0.2 \mu \mathrm{m})$ prior to use. The FITC-casein resulted in some general FITC-staining of protists and bacteria in a preliminary experiment employing this subtrate. Assuming that this was due to the presence of non-conjugated FITC, we isolated the high molecular weight fraction by gel filtration through a prepacked Sephadex G-25 column (PD-10, Pharmacia, Uppsala, Sweden). After this treatment, the general staining by FITC-casein was reduced, but not totally eliminated. For uptake experiments, $10 \mathrm{ml}$ subsamples were incubated with FITCsubstrate at $1 \mathrm{mg} \mathrm{l}^{-1}$ or $10 \mathrm{mg} \mathrm{l}^{-1}$ for $2 \mathrm{~h}$ at $15^{\circ} \mathrm{C}$ in the dark, and fixed by the Lugol-formaldehyde-thiosulfate method. Control samples were fixed before adding the FITC-substrate.

To check for the appearance of aggregates of the FITC-labeled compounds, the compounds were incubated with $0.2 \mu \mathrm{m}$ filtered seawater or HPLC grade water for $4 \mathrm{~h}$ at $10 \mathrm{mg} \mathrm{l}^{-1}$ in the dark at room temperature. Subsamples of $1 \mathrm{ml}$ were filtered onto $25 \mathrm{~mm}$ diameter $0.2 \mu \mathrm{m}$ polycarbonate filters (Poretics, Livermore, CA, USA), and 0.2 and $0.02 \mu \mathrm{m}$ aluminum filters (Anopore, Anotec Separations, New York, NY, USA) for microscopic examination of FITC-fluorescing particles. 
To assess the relationship between the growth state of bacterivorous flagellates and their ability to ingest macromolecules, we assayed for both the ingestion of FITC-labeled dextran, ferritin, and con A, as well as clearance rate for $0.5 \mu \mathrm{m}$ blue fluorescent sulfate polystyrene latex beads (Interfacial Dynamics Corp., Portland, OR, USA) as an analogue of bacterivory. Samples were taken at various stages of the growth curve for 2 replicate cultures of $\mathrm{E} 4$ grown at $15^{\circ} \mathrm{C}$ in the dark in filtered seawater, amended with $10 \mathrm{mg}$ yeast extract $\mathrm{l}^{-1}$ to stimulate the growth of bacterial prey. FITC-substrate uptake was determined after $2 \mathrm{~h}$ of incubation with $10 \mathrm{mg}$ FITC-substrate $\mathrm{l}^{-1}$. From one of the cultures, killed controls were examined for uptake of FITC-labeled substrates. Bead uptake rate was derived from linear regression of numbers of beads ingested per flagellate after $0,15,30$, and 45 min of incubation of subsamples amended with beads. The bead abundance was 31 to $64 \%$ of the bacterial abundance for each occasion the uptake rate was determined. Samples were stained with acridine orange and flagellates were detected under blue excitation. For each flagellate encountered (at least 50 flagellates were examined for each sample) the abundance of the fluorescent beads in the vacuoles was quantified using UV excitation.

In additional experiments, the effect of dextran on flagellate ingestion of bacteria was studied. Subsamples of $10 \mathrm{ml}$ from an E4 flagellate culture, grown on $10 \mathrm{mg}$ yeast extract $\mathrm{l}^{-1}$ (see above), were incubated for $4 \mathrm{~h}$ prior to experiments with $2000 \mathrm{kD}$ dextran (nonfluorescent) at concentrations of 0 to $100 \mathrm{mg}$ dextran $\mathrm{l}^{-1}$. Fluorescent labeled bacteria (FLB; prepared according to Sherr et al. 1987) were added at an abundance of $10^{6} \mathrm{I}^{-1}$, and the samples were fixed after $30 \mathrm{~min}$ of incubation at $15^{\circ} \mathrm{C}$ by the Lugol-formaldehyde-thiosulfate method. At least 50 flagellates were inspected in each sample, and the average number of ingested beads was determined and corrected for 'ingested' beads in time 0 controls. In a similar experiment, no dextran was added prior to FLB uptake assays, but the FLB's were preconditioned overnight at $4{ }^{\circ} \mathrm{C}$ in the dark in dextran solutions at concentrations of 0 to $2000 \mathrm{mg}$ dextran $^{-1}$ (yielding a final concentration during experiments of 0 to $20 \mathrm{mg}$ dextran $\mathrm{l}^{-1}$ ), to obtain a dextran coating of the FLB.

Growth experiments. To obtain flagellate cultures with low abundance of bacteria for the study of growth at the expense of macromolecules, a flagellate culture (E4) was inoculated into $0.2 \mu \mathrm{m}$ filtered, aged seawater, that was amended with $10^{7}$ heat-killed bacteria $\mathrm{ml}^{-1}$ [prepared from a bacterial isolate according to the procedure by Sherr et al. (1987) for the preparation of fluorescent labeled bacteria, but without using fluorochrome]. In this way bacterial prey was added, but a minimum of dissolved substrates for additional bacterial growth was provided. After $5 \mathrm{~d}$ of growth at $15^{\circ} \mathrm{C}$ in the dark, the cultures were diluted 4 times with $0.2 \mu \mathrm{m}$ filtered aged seawater to further decrease the bacterial abundance, and divided into $100 \mathrm{ml}$ replicates in tissue culture flasks, some of which were amended with bacterial inhibitors $\left(200 \mathrm{mg} \mathrm{l}^{-1}\right.$ vancomycin + $1 \mathrm{mg} \mathrm{l}^{-1}$ penicillin; Sherr et al. 1986) to selectively inhibit bacterial growth. The cultures were left $1 \mathrm{~d}$ for the protists to recover from possible direct effects of the antibiotics. Thereafter, substrate was added at $10 \mathrm{mg} \mathrm{l}^{-1}$ to some of the replicates, and abundance of bacteria and flagellates was followed over several days. Cultures with bacteria in the absence of flagellates were obtained by screening through $0.8 \mu \mathrm{m}$ polycarbonate filters. Growth experiments were tried with dextran $(40$ and $2000 \mathrm{kD}$, ferritin, LPS, albumin, and extracellular polysaccharides extracted from cultures of a marine bacterium, Pseudomonas atlantica (ATCC 43667). Only dextran results are reported here. Antibiotics seemed to efficiently inhibit increase in bacterial abundance, but the bacterial cell volumes increased markedly when the other substrates were added. This was not the case with dextran, which apparently was not utilized to a great extent by bacteria. Thus, for the other substrates it was not possible to distinguish direct flagellate utilization of the substrates from indirect effects due to increased biovolume of bacterial prey.

\section{RESULTS AND DISCUSSION}

\section{Uptake of macromolecules}

Most of the FITC-labeled substrates contained no particulate materials retained on filters with pores $\geq 0.02 \mu \mathrm{m}$ that could be detected by microscopy. Also, most did not form fluorescent particles when added to filtered seawater. Exceptions to this were LPS and albumin. LPS (prepared by Sigma by extraction of Escherichia coli cells with phenol) contained numerous brightly fluorescent bacterial-shaped particles, and consisted largely of fluorescent irregular aggregates ca 0.1 to $0.5 \mu \mathrm{m}$ in size. Due to the obvious particulate appearance, we did not filter LPS before addition to samples. Albumin contained some tiny fluorescent dots, that could be observed on 0.02 and $0.2 \mu \mathrm{m}$ Anopore filters, but not on the $0.2 \mu \mathrm{m}$ Poretics filter. Dextran appeared to give a background fluorescence on $0.02 \mu \mathrm{m}$ filters, but not on $0.2 \mu \mathrm{m}$ filters, brighter than the dim background fluorescence of control filters without added FITC compounds. The fluorescence was amorphous, without any distinguishable brighter dots, suggesting that the high MW dextran passed through 
the $20 \mathrm{~nm}$ pores inefficiently. All other substrates (ferritin, casein, con A) appeared to be truly dissolved, or occurred in a form that could readily pass the pores of the filters. Moreover, all substrates behaved similarly in reagent grade water and in seawater. Hence, it is likely that any observed uptake into flagellates was due to uptake of the pure substrate or aggregates $<20 \mathrm{~nm}$ formed by the substrate, except for LPS and possibly also albumin.

All the FITC-compounds investigated were ingested by both the cultured flagellate (Table 1), and by flagellates of the mixed assemblages (Table 2). As in the previous study (Sherr 1988), ingested FITC did not seem to be associated with ingested bacteria or other particles. The only noticeable labeling outside of protist vacuoles was by con $\mathrm{A}$ in the mixed assemblages. where some FITC fluorescence was found in conjunction with algal surfaces and detritus particles. In preparations of the cultured species, fluorescence was always observed in 1 to 3 food vacuoles in the region of the cell opposite the flagella, the same area in which ingested bacteria and bacterial-sized fluorescent microspheres are found in grazing experiments with this flagellate. Thus, the FITC-labelled macromolecules appeared to have been ingested by phagocytosis, similar to the ingestion of much larger food items.

Con A fluorescence was also found in a large proportion of flagellates in killed controls. In the experiments with the E4 flagellate with the most vigorous uptake into live cells, the uptake into killed flagellates could easily be judged as being less bright, and the fluorescence appeared to emanate from a layer around the edge of the vacuoles rather than from a dense body of FITC-labelled material, as in the live samples. The fact that killed flagellates also took up some con A suggests that the uptake, at least to some extent, was due to a specific biochemical reaction, rather than an active, unspecific phagocytosis of colloidal DOM.

Table 1 Fraction (\%) of cultured flagellates (live and killed control) with fluorescent labelled food vacuoles after $2 \mathrm{~h}$ at $15^{\circ} \mathrm{C}$ with FITC-marked substrates added at 1 and $10 \mathrm{mg} \mathrm{l}^{-1}$. E4 culture started with heat-killed bacteria, $5 \mathrm{~d}$ old $(2.3 \times$ $10^{6}$ bacteria $\mathrm{ml}^{-1}, 0.27 \times 10^{6}$ flagellates $\mathrm{ml}^{-1}$ ). Casein was studied separately in a similar culture $\left(15.9 \times 10^{6}\right.$ bacteria $\mathrm{ml}^{-1}$ and $11.5 \times 10^{3}$ flagellates $\mathrm{ml}^{-1}$ ). LPS: Lipopolysaccharide; Con $\mathrm{A}$ : concavalin $\mathrm{A}_{i}-$ : not measured

\begin{tabular}{|crrrrrrr}
\hline & Dextran & LPS & Albumin & Ferritin & Con A Casein \\
\hline $1 \mathrm{mg} \mathrm{l}^{-1}$ & & & & & & \\
$\quad \begin{array}{l}\text { Killed } \\
\text { Live }\end{array}$ & 0.0 & 1.6 & 1.0 & 0.8 & 19.2 & - \\
10.1 & 16.5 & 73.9 & 80.3 & 97.7 & - \\
$\begin{array}{c}10 \mathrm{mg} \mathrm{l}^{-1} \\
\text { Killed } \\
\text { Live }\end{array}$ & 0.0 & 53.0 & 68.0 & 66.7 & 85.3 & 97.7 & 37.6 \\
\hline
\end{tabular}

Table 2. Fraction (\%) of in situ flagellates (live and killed control) with fluorescent labeled food vacuoles after $2 \mathrm{~h}$ at $15^{\circ} \mathrm{C}$ with FITC-marked substrates added at 1 and $10 \mathrm{mg} \mathrm{l}^{-1}$ Samples from Oregon, USA, coastal waters. (A) Samples screened $(20 \mu \mathrm{m})$ and incubated $2 \mathrm{~d}\left(2.3 \times 10^{6}\right.$ bacteria $\mathrm{ml}^{-1}, 2.1$ $\times 10^{3}$ flagellates $\mathrm{ml}^{-1}$ ). (B) Samples enriched with yeast extract $\left(10 \mathrm{mg} \mathrm{I}^{-1}\right)$, incubated $7 \mathrm{~d}\left(3.3 \times 10^{6}\right.$ bacteria $\mathrm{ml}^{-1}, 57 \times 10^{3}$ flagellates $\mathrm{ml}^{-1}$ ). Abbreviations as in Table 1

\begin{tabular}{|c|c|c|c|c|c|c|}
\hline & Dextran & LPS & Albumin & Ferritin & Con $\mathrm{A}$ & Casein \\
\hline \multicolumn{7}{|l|}{ (A) $1 \mathrm{mg} \mathrm{l}^{-1}$} \\
\hline Killed & 0.0 & 5.2 & 5.9 & 4.0 & 1.0 & - \\
\hline Live & 10.0 & 31.1 & 27.6 & 13.0 & 23.5 & - \\
\hline \multicolumn{7}{|l|}{$10 \mathrm{mg} \mathrm{l}^{-1}$} \\
\hline Killed & 0.0 & 8.9 & 0 & 1.0 & 5.4 & - \\
\hline Live & 15.8 & 39.6 & 27.2 & 17.3 & 30.6 & - \\
\hline \multicolumn{7}{|l|}{ (B) $10 \mathrm{mg} \mathrm{l}^{-1}$} \\
\hline Killed & 0.0 & ND & 2.9 & 3.9 & 13.0 & 2.8 \\
\hline Live & 43.7 & ND & 50.0 & 19.6 & 58.8 & 48.1 \\
\hline
\end{tabular}

Thus, lectin-binding sites in food vacuoles may be involved in prey recognition and ingestion in protists. In other studies of lectin-binding sites involving con $\mathrm{A}$, binding has been found to be efficient also in fixed organisms (Jansson et al 1986). Killed controls were incubated with the FITC-substrates for as long as the live samples. Occasional time zero controls were also performed with con A. In these controls, uptake was detectable in only a few percent of the cells.

Ingestion of all compounds was observed in flagellates in the fresh field sample, but not quantified. Flagellate abundance was too low to practially allow quantification of the uptake (460 flagellates $\mathrm{ml}^{-1}$ and $0.82 \times 10^{6}$ bacteria $\mathrm{ml}^{-1}$ ), as it was necessary to filter volumes so large that detritus obscured the detection of FITC. In samples that were incubated for $2 \mathrm{~d}$, the various substrates were incorporated into 15 to $30 \%$ of the flagellates (Table 2). In samples enriched with $10 \mathrm{mg}$ yeast extract $\mathrm{l}^{-1}$ and incubated for $7 \mathrm{~d}$, roughly half of the flagellates in live samples ingested several of the substrates (Table 2). Protists with ingested FITC included 3 to $10 \mu \mathrm{m}$ monads and some choanoflagellates. Forms that were never found with ingested FITC included a naked heterotrophic dinoflagellate and choreotrichous ciliates. No uptake was detected in flagellates with chlorophyll autofluorescence.

\section{Uptake versus growth state}

Abundance of flagellates and bacteria, clearance rate for $0.5 \mu \mathrm{m}$ latex beads and uptake of dextran, ferritin, and con A were followed in batch cultures of the E4 flagellate. Bacteria reached maximal density within $3 \mathrm{~d}$; thereafter they rapidly decreased, and 
remained at 2 to $3 \times 10^{6}$ cells $\mathrm{I}^{-1}$ for the rest of the experiment (Fig. 1). Concomitant with the decrease in bacterial standing stock, the flagellate populations increased to their maximal abundance, from which they continously decreased during the remainder of the experiment (Fig. 1). The specific clearance rate of the flagellates for $0.5 \mu \mathrm{m}$ beads was highest during the time of bacterial decrease, apparently due to intensive bacterivory (Fig. 2). Thereafter the clearance rate decreased succesively with age of the cultures. The fraction of the flagellates with ingested FITC-dextran, ferritin and con A exhibited a similar pattern (Fig. 2). As in the previous experiments, con A was taken up to a considerable extent also in killed controls. Towards the end of the experiment, the fraction of the cells with con A was similar in live and killed samples.

The only quantification of uptake of macromolecules we were able to do was to detect the fraction of the flagellate population that had a detectable amount of FITC-substrate in the food vacuoles. This fraction increased asymptotically with increasing clearance rate, and there was a positive correlation between clearance rate for beads and fraction of cells with ingested FITC-
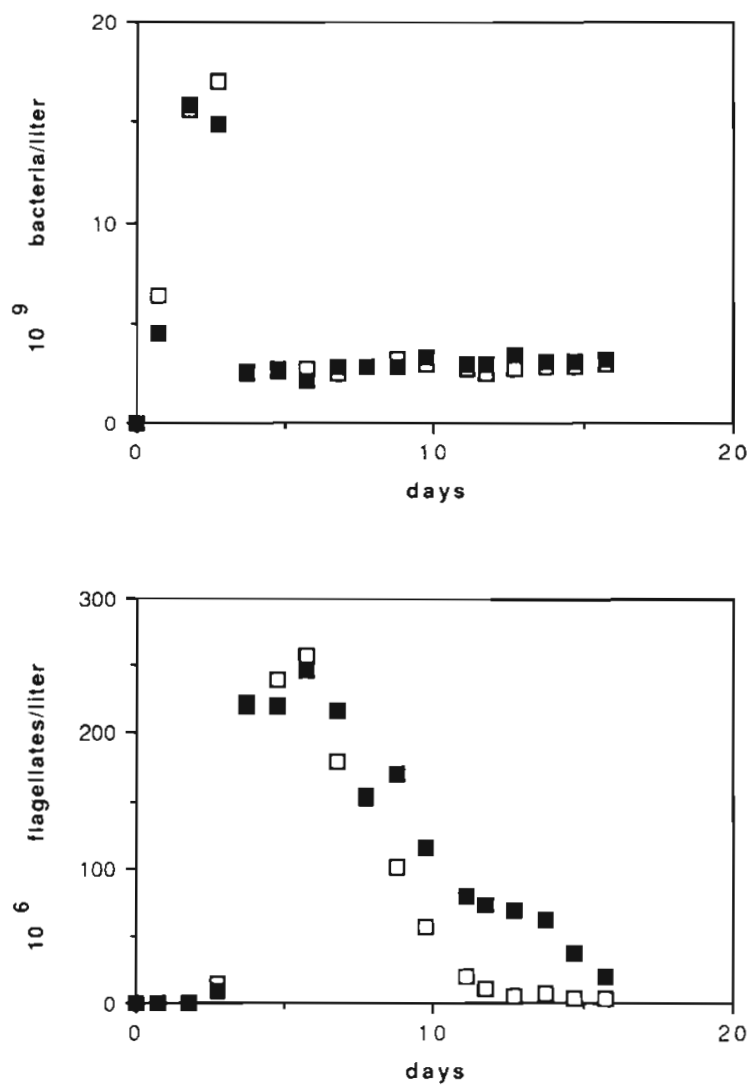

Fig. 1. Abundance of bacteria and E4 flagellates in 2 cultures ( $\square$ and $\square$ ). The cultures were subsampled for experiments on the uptake of $0.5 \mu \mathrm{m}$ latex beads, dextran, ferritin, and concavalin $A$ at various times (see Fig. 2) substrate (Fig. 3). Possibly, if we were able to quantify the absolute amount of fluorescent compound incorporated per flagellate, we would find a linear relationship between clearance rate for bacterial-sized beads and macromolecules. There was no sequential pattern in the uptake of beads and macromolecules, but rather a general simultaneous uptake of food items spanning a wide range of sizes. Possibly, the clearance rates for the macromolecules were much lower than the clearance rate for bacterial-sized particles, in line with the lower clearance rate demonstrated for small bacteria, as compared to large bacteria (González et al. 1990), and for viruses, as compared to bacteria (González \& Suttle 1993).

\section{Effect of dextran on uptake of bacterial-sized particles}

In flagellate cultures amended with dextran, the uptake of FLB was similar over a wide range of dextran concentrations (Fig. 4). Similarly, FLB were ingested at similar rates regardless of whether they were preconditioned in dextran at concentrations up to $2000 \mathrm{mg} \mathrm{l}^{-1}$ (Fig. 4). Thus, even when offered a macromolecular food source at very high concentration, flagellate consumption of bacterial-sized food items was unaffected.

\section{Growth experiments}

In a preliminary growth experiment with dextran, changes in abundance of flagellates and bacteria leveled out within $4 \mathrm{~d}$. Thus, response of the microbes to additions of dextran was measured as biovolume change over $96 \mathrm{~h}$. In cultures without dextran or with $40 \mathrm{kD}$ dextran there was no significant change in flagellate biovolume (Table 3). This was the case both in cultures where bacterial activity was inhibited by antibiotics and in cultures without antibiotics. In cultures with added $2000 \mathrm{kD}$ dextran flagellate biovolume increased (Table 3). The increase in biovolume was a consequence of both increased cell volumes and increased abundance. In the presence of $2000 \mathrm{kD}$ dextran, average cell volume increased from $11.2 \pm$ $1.5 \mu \mathrm{m}^{3}$ at the beginning of experiments to $22.9 \pm$ $1.1 \mu \mathrm{m}^{3}$ after $96 \mathrm{~h}$ (average $\pm \mathrm{SD}, \mathrm{n}=8$ ), with no significant difference between treatments with and without antibiotics. Cell volume in all other treatments was similar and did not change over time $\left(10.8 \pm 1.2 \mu \mathrm{m}^{3}\right.$

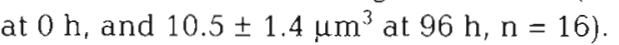

In cultures without antibiotics there were either no or minor changes in bacterial biovolume (Table 3), probably because grazing losses were largely compensated by growth. In the presence of antibiotics, 

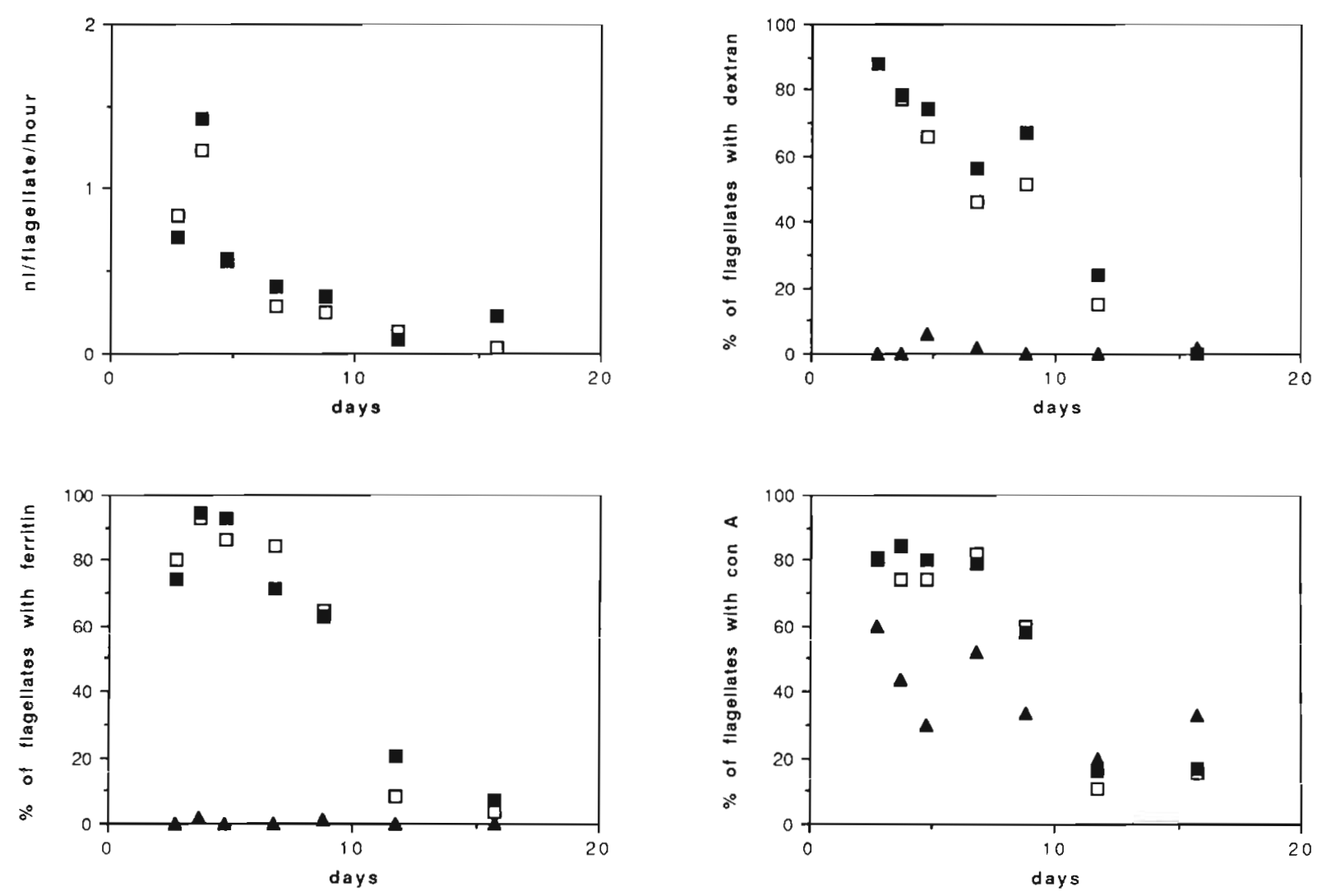

Fig. 2. Clearance rate for $0.5 \mu \mathrm{m}$ beads and fraction of flagellates ingesting dextran, ferritin, and concavalin $A$ in the cultures depicted in Fig. 1. (4) Fraction of cells with ingested substrate in killed controls from one of the cultures

bacterial biovolume decreased during the experiment. In cultures where the flagellates had been removed, there was a pronounced bacterial growth (Table 3), apparently due to absence of grazing pressure. The bacterial growth in flagellate-free cultures was only stimulated by dextran to a minor extent. Bacterial volumes per cell were similar in flagellate cultures

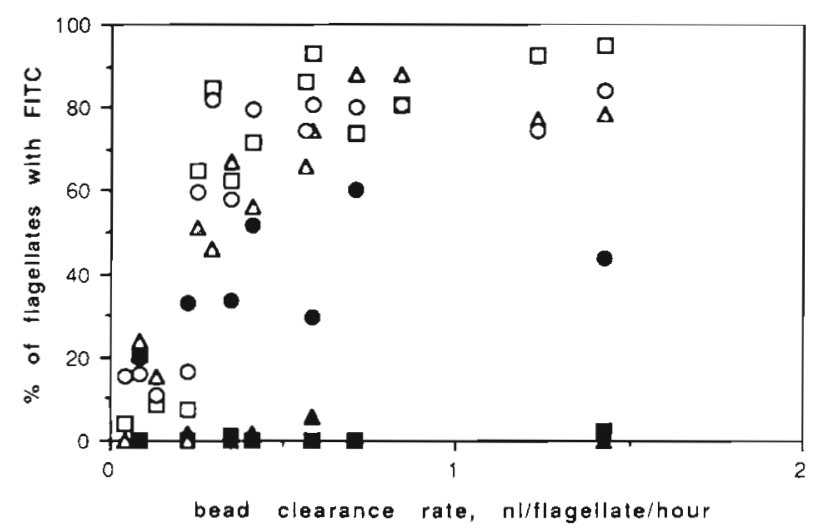

Fig. 3. Fraction of flagellates with ingested dextran $(\Delta, \mathbf{\Delta})$, ferritin $(\square, \mathbf{m})$, and concavalin $A(O, \bullet)$ as a function of clearance rate. Open symbols: live samples; filled symbols: killed controls with and without antibiotics, and in cultures with and without 40 or $2000 \mathrm{kD}$ dextran. However, cell volumes decreased in all treatments from 0 to $96 \mathrm{~h}$ (from $0.16 \pm 0.01$ to $0.13 \pm 0.01 \mu \mathrm{m}^{3}, \mathrm{n}=24$, average for all treatments \pm SDj. Thus, changes in bacterial cell volumes were not correlated with the presence of dextran or antibiotics, but decreased in presence of flagellates, as can be expected during size-selective grazing (Andersson et al. 1985, González et al. 1990).

We can make a general calculation of dextran utilization by flagellates in the growth experiments. A wide range of volume to carbon conversion factors have been reported for bacteria and flagellates, and it should be recognized that the combination of factors chosen will influence the outcome of the analysis. If we assume an equal carbon to volume ratio of $0.2 \mathrm{pg} \mu \mathrm{m}^{-3}$ for both preserved flagellates and bacteria (this is within the range of reported values; Bratbak 1985, Bjørnsen 1986, Børsheim \& Bratbak 1987, and references therein), and assume a flagellate net growth efficiency of $50 \%$, the difference in bacterial response between cultures with and without $2000 \mathrm{kD}$ dextran cannot account for the flagellate production (Table 4). With the same conversion factor, the final flagellate carbon yield corresponded to about $1 \%$ of the dextran 

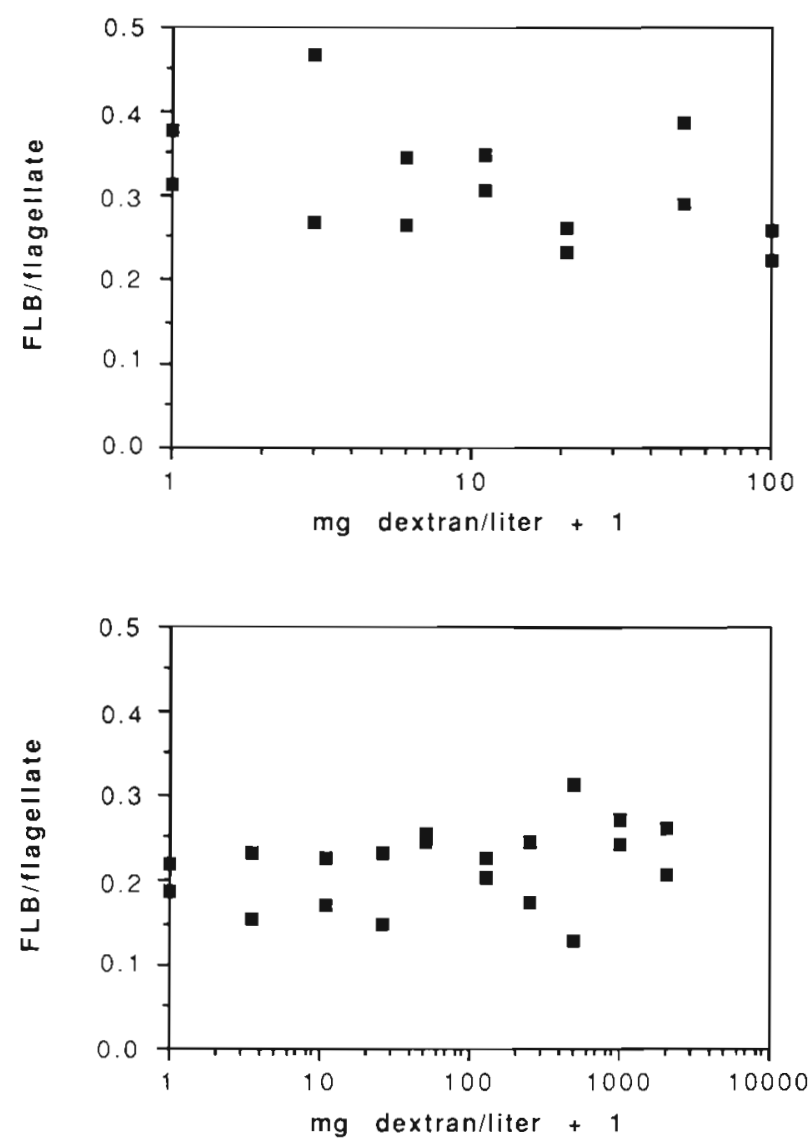

Fig. 4. Average number of ingested fluorescent labelled bacteria (FLB) per flagellate in cultures preconditioned with $2000 \mathrm{kD}$ dextran at different concentrations (upper panel) and in cultures amended with FLB's preconditioned with dextran at various concentrations (lower panel) carbon added. Thus, the degree of dextran utilization was low, especially as some of the flagellate carbon yield was probably due to feeding on bacteria. Although the dextran was utilized with low efficiency, this experiment yields reasonable evidence that it contributed to flagellate growth. A possible hypothesis would be that dextran is ingested accidentally along with bacteria, resulting in a 'reverse sloppy feeding'. However, such a mechanism would result in equal utilization of 40 and $2000 \mathrm{kD}$ dextran. This was not the case, and, accordingly, $40 \mathrm{kD}$ FITC-dextran was not ingested into food vacuoles (preliminary observations; Sherr 1988). Thus, it is probable that $2000 \mathrm{kD}$ dextran contributed to flagellate nutrition due to the ability of the flagellates to phagocytize larger colloidal sized macromolecules, but not similar molecules of much smaller size.

\section{CONCLUSIONS}

In this paper, we present evidence that a variety of macromolecules, including carbohydrates (dextran) and proteins (ferritin, casein, albumin, concavalin A) are actively ingested by heterotrophic flagellates at concentrations in the same range as the total organic carbon concentration of pelagic waters. Furthermore, we demonstrate that the uptake was not due to larger aggregates of the FITC-substrates, or passive staining of food vacuoles. Flagellates have the potential to ingest a variety of macromolecules into their food vacuoles, which suggests to us that naturally occurring colloids of similar size may also be ingested by protists.

Table 3. Microbial biovolume ( $\mathrm{nl}$ biovolume $\mathrm{l}^{-1}$ water $\pm \mathrm{SD}$ for 4 replicates) at beginning ( $0 \mathrm{~h}$ ) and end ( $96 \mathrm{~h}$ ) of incubation with and without the addition of $10 \mathrm{mg}$ of $40 \mathrm{kD}$ or $2000 \mathrm{kD}$ dextran $\mathrm{l}^{-1}$. NS: change in biovolume not significant at $\mathrm{p}<0.05(2$-tailed paired $t$-test); -: not measured

\begin{tabular}{|c|c|c|c|c|c|c|}
\hline & \multicolumn{3}{|c|}{ Without antibiotics } & \multicolumn{3}{|c|}{ With antibiotics } \\
\hline & $\begin{array}{l}\text { Dextran } \\
2000 \mathrm{kD}\end{array}$ & $\begin{array}{c}\text { Dextran } \\
40 \mathrm{kD}\end{array}$ & No dextran & $\begin{array}{l}\text { Dextran } \\
2000 \mathrm{kD}\end{array}$ & $\begin{array}{c}\text { Dextran } \\
40 \mathrm{kD}\end{array}$ & No dextran \\
\hline \multicolumn{7}{|l|}{ Flagellates } \\
\hline $\mathrm{oh}$ & $77.7 \pm 23$ & $69.3 \pm 13$ & $78.8 \pm 14$ & $97.9 \pm 36$ & $105 \pm 17$ & $87.8 \pm 11$ \\
\hline $96 \mathrm{~h}$ & $246 \pm 44$ & $78.1 \pm 18$ & $60.2 \pm 14$ & $301 \pm 45$ & $70.7 \pm 22$ & $77.0 \pm 30$ \\
\hline Change & $169 \pm 38$ & NS & NS & $203 \pm 41$ & NS & NS \\
\hline \multicolumn{7}{|l|}{ Bacteria } \\
\hline $\mathrm{Oh}$ & $260 \pm 23$ & $239 \pm 29$ & $243 \pm 18$ & $223 \pm 19$ & $191 \pm 16$ & $183 \pm 30$ \\
\hline $96 \mathrm{~h}$ & $225 \pm 31$ & $223 \pm 8.5$ & $293 \pm 74$ & $122 \pm 12$ & $122 \pm 13$ & $146 \pm 15$ \\
\hline Change & $-34.7 \pm 21$ & NS & NS & $-101 \pm 21$ & $-68.3 \pm 22$ & $-36.9 \pm 19$ \\
\hline \multicolumn{7}{|c|}{ Bacteria in the absence of flagellates } \\
\hline $0 \mathrm{~h}$ & $48.9 \pm 7.7$ & - & $47.5 \pm 3.0$ & - & - & - \\
\hline $96 \mathrm{~h}$ & $358 \pm 60$ & - & $308 \pm 64$ & - & - & - \\
\hline Change & $309 \pm 65$ & - & $261 \pm 66$ & - & - & - \\
\hline
\end{tabular}


Thus, we confirm the indication by Sherr (1988) of a possible high molecular weight/colloidal DOM $\rightarrow$ protist pathway in pelagic carbon cycles. In addition, we demonstrate that high molecular weight carbohydrates (dextran) directly support biovolume production in cultures of a marine, heterotrophic flagellate. Protists have the capacity to ingest colloids of various sizes, spanning the size range from bacteria and larger organisms (Fenchel 1982, Sieburth \& Davis 1982, Sherr \& Sherr 1984) to viral particles (González \& Suttle 1993) and possibly sub-micrometer colloids (sensu Koike et al. 1990, Wells \& Goldberg 1991) to macromolecules (Sherr 1988, this study).

Uptake capacity for high MW substrates was correlated with the uptake of bacterial size prey, and bacterivory was not affected by the presence of an available source of high MW substrate, even at very high concentrations. Thus, the uptake of high MW DOM and bacterial size prey appeared to occur by the same mechanisms (indicated also by the appearance of high MW DOM in food vacuoles similar to vacuoles containing bacteria), and flagellates were not able to selectively ingest one of the sources. The degree of utilization of dextran by the flagellates was low in growth experiments, and richer high MW substrates could not be used for these experiments due to vigorous growth of bacteria that made the study of the direct $\mathrm{DOM} \rightarrow$ flagellate pathway ambiguous. This indicates that, in terms of total carbon flow, heterotrophic flagellates play only a minor role in the processing of high MW DOM. It remains to be demonstrated whether this is the case also for naturally occurring macromolecules and small colloids. It has recently been demonstrated that DOM covers a continuum of colloidal size classes, the largest being similar to bacteria in size (Koike et al. 1990, Wells \& Goldberg 1991). This insight, together with the discovery of protistan phagocytosis of colloids much smaller than bacteria (Sherr 1988, Gonzâlez \& Suttle 1993, this study), suggests that sources of nutrition in heterotrophic nanoflagellates, often assumed as equivalent to bacterivorous nanoflagellates, may be more diverse than usually believed. In addition to being a source of energy, uptake of colloidal DOM may be of significance in other respects. Food items of subbacterial size with high $\mathrm{C} / \mathrm{N}$ and $\mathrm{C} / \mathrm{P}$ ratios may serve in balancing the diet of protists, as bacteria, the major food source of many protists, are more enriched than protists in $N$ and $P$ (Sleigh 1989). Conversely, colloidat DOM rich in $N$ and $P$, e.g. virus particles, would provide nutrients during the feeding on carbon rich substrates, such as detritus particles. There may be differences between different protist taxa in their ability to utilize food items of sub-bacterial size. In their study of protist grazing on viruses, González \& Suttle 1993) noted that choanoflagellates were able to ingest viral- sized particles (50 $\mathrm{nm}$ latex beads) but not bacterialsized beads (500 $\mathrm{nm}$ latex beads). Marchant (1990) also reported that choanoflagellates inefficiently ingested latex beads larger than $500 \mathrm{~nm}$.

Acknowledgements. This study was supported by grants from the Swedish Natural Science Research Council and the Swedish Institute to L. Tranvik, and by NSF grants OCE-8816428 to E. Sherr and B. Sherr and OCE-8823091 to B. Sherr and E. Sherr

\section{LITERATURE CITED}

Andersson, A., Lee, C., Azam, F., Hagström, §. (1985). Release of amino acids and inorganic nutrients by heterotrophic marine microflagellates. Mar. Ecol. Prog. Ser. 23: $99-106$

Bergh, Ø., Børsheim, K. Y., Bratbak, G., Heldal, M. (1989). High abundance of viruses found in aquatic environments. Nature 340: 467-468

Bjørnsen, P. K. (1986). Automatic determination of bacterioplankton biomass by image analysis. Appl. environ. Microbiol. 51. 1199-1204

Børsheim, K. Y., Bratbak, G. (1987). Cell volume to cell carbon conversion factors for a bacterivorous Monas sp. enriched from seawater. Mar. Ecol. Prog. Ser. 36: 171-175

Bratbak, G. (1985). Bacterial biovolume and biomass estimations. App. environ. Microbiol. 49: 1488-1493

Fenchel, T (1982). Ecology of heterotrophic microflagellates IV Quantitative occurrence and importance as bacterial consumers. Mar. Ecol. Prog. Ser. 9: 35-42

Fenchel, T (1987). Ecology of Protozoa. The biology of freeliving phagotrophic protists. Brock/Springer series in contemporary bioscience. Springer-Verlag, Berlin

Gast, V. (1985). Bacteria as a food source for microzooplankton in the Schlei Fjord and Baltic Sea with special reference to ciliates. Mar. Ecol. Prog. Ser. 51: 215-220

González, J. M., Sherr, E. B., Sherr, B. F. (1990). Size-selective grazing on bacteria by natural assemblages of estuarine flagellates and ciliates. Appl. environ. Microbiol. 56: $583-589$

González, J. M., Suttle, C. A. (1993). Grazing by marine nanoflagellates on viruses and viral-sized particles: ingestion and digestion. Mar. Ecol. Prog. Ser. (in press)

Haas, L. W., Webb, K. L. (1979). Nutritional mode of several non-pigmented microflagellates from the York River estuary, Virginia. J. exp. mar. Biol. Ecol. 39: 125-134

Hobbie, J. E., Daley, R., Jasper, S. (1977). Use of Nuclepore filters for counting bacteria by fluorescence microscopy. Appl. environ. Microbiol. 33: 1225-1228

Jansson, H.-B., Jeyaprakash, A., Coles, G. C., MarbanMendoza, N., Zuckerman, B. M. (1986). Fluorescent and ferritin labelling of cuticle surface carbohydrates of Caenorhabditis elegans and Panagrellus redivivus. J. Nematol. 18: 570-574

Koike, I., Hara, S., Terauchi, K., Kogure, K. (1990). Role of sub-micrometre particles in the ocean. Nature 345: 242-244

Marchant, H. J. (1990). Grazing rate and particle size selection by the choanoflagellate Diaphanoeca grandis from the sea-ice of Lagoon Saroma Ko, Hokkaido. Proc. NIPR Symp. Polar Biology 3: 1-7

Sherr, B. F., Sherr, E. B. (1984). Role of heterotrophic protozoa in carbon and energy flow in aquatic ecosystems. In: Klug, M. J., Reddy, C. A. (eds.) Current perspectives in microbial 
ecology. American Society for Microbiology, Washington, DC, p. $412-423$

Sherr, B. F., Sherr, E. B., Andrew, T. L., Fallon, R. D., Newell, S. Y. (1986). Trophic interactions between heterotrophic protozoa and bacterioplankton in estuarine water analyzed with selective metabolic inhibitors. Mar. Ecol. Prog. Ser. 32: 169-179

Sherr, B. F., Sherr, E. B., Fallon, R. D. (1987). Use of monodispersed, fluorescently labeled bacteria to estimate in situ protozoan bacterivory. Appl. environ. Microbiol. 53: 958-965

Sherr, E. B. (1988). Direct use of high molecular weight polysaccharide by heterotrophic flagellates. Nature 335 : 348-351

Sherr, E. B., Caron, D. A., Sherr, B. F. (1993). Staining of heterotrophic protists for visualization via epifluorescence microscopy. In: Kemp, P., Cole, J., Sherr, B., Sherr, E. (eds.) Current methods in aquatic microbial ecology. Lewis Publ., in press

This article was submitted to the editor
Sherr, E. B., Sherr, B. F. (1992). Trophic roles of pelagic protists: phagotrophic flagellates as herbivores. Archiv Hydrobiol. Beih. Ergebn. Limnol. 37: 165-172

Sieburth, J. McN. (1979). Sea microbes. Oxford Univ. Press, New York

Sieburth, J. McN., Davis, P. G. (1982). The role of heterotrophic nanoplantkon in the grazing and nurturing of planktonic bacteria in the Sargasso and Carribean seas. Annls. Inst. océanogr., Paris 58: 285-296

Sleigh. M. A. (1989). Protozoa and other protists. Edward Arnold, London

Stockner, J. G., Klut, M. E., Cochlan, W. P. (1990). Leaky filters: a warning to aquatic ecologists. Can. J. Fish. Aquat. Sci 47: $16-23$

Tranvik, L. J. (1988). Availability of dissolved organic carbon for planktonic bacteria in oligotrophic lakes of differing humic content. Microb. Ecol. 16: 311-322

Wells, M. L., Goldberg, E. D. (1991). Occurrence of small colloids in sea water. Nature 353: $342-344$

Manuscript first received: June 15, 1992

Revised version accepted: November 30, 1992 